\title{
Searching for Active Ingredients in Edible Bird's Nest
}

\author{
Gallant KL Chan ${ }^{1,2 *}$, Kevin QY Wu ${ }^{1,2}$, Aster HY Fung ${ }^{2}$, Karmen KM Poon ${ }^{2}$, Caroline Y Wang ${ }^{2}$, Elizaveta Gridneva ${ }^{2}$, \\ Rena RH Huang ${ }^{1}$, Sisley YZ Fung ${ }^{1,2}$, YT Xia ${ }^{1,2}$, Winnie WH Hu ${ }^{1}$, Zack CF Wong ${ }^{1,2}$ and Karl WK Tsim ${ }^{1,2}$
}

${ }^{1}$ Shenzhen Key Laboratory of Edible and Medicinal Bioresources, Shenzhen Research Institute, China

${ }^{2}$ Division of Life Science and Center for Chinese Medicine, The Hong Kong University of Science and Technology, China

Submission: April 03, 2018; Published: May 14, 2018

*Corresponding author: Gallant KL Chan, Division of Life Science and Center for Chinese Medicine, The Hong Kong University of Science and Technology, Clear Water Bay, Hong Kong, China, Email: gallant@ust.hk

\section{Abstract}

Edible bird's nest (EBN; cubilose) is an ancient Chinese delicacy, made of the salivary secretion of specific swiftlets (such as Aerodramusfuciphagus), which has been consumed for several hundred years. Until now, EBN is still a popular luxurious food supplement for women in oriental regions. According to traditional Chinese medicinal descriptions, EBN can promote the "Qi", corresponding to the lung/ respiratory functions; and hence which improves the healthiness of skin. However, the underlying mechanism of this medicinal theory is still largely unknown. In this review, we provided a comprehensive overview for chemical composition and biological properties of EBN.

\section{Introduction}

Edible bird's nest (EBN; cubilose), a well-known traditional food, used in Asia, has various nutritious and/or medicinal properties, e.g. anti-inflammatory [1], anti-influenza [2,3], skin regeneration and bone strengthening [4]. EBN is the salivary secretion from the species of swiftlets, i.e. Aerodramusfuciphagus and Aerodramus maximus [5]. By color, EBNs can be divided into white, yellow and red. White EBN accounts for over $90 \%$ of EBN supply. The formation of Yellow and Red EBN are proposed to be an oxidized products of White EBN. In the market, Red EBN is most expensive than others. According to the historical record in AD 1700 (Qing dynasty in China), e.g. "Ben Cao Feng Yuan" and "Ben Cao Gang Mu Shi Yi”, Red EBN possesses additional function of replenish blood, as compared to that of White EBN. Due to the restricted supply in the market, EBN has a high price with a range from US\$1,000 - 15,000 per kilogram in the food market.

\section{N-Acetylneuraminic Acid - An Indicative Quality Control Marker for EBN}

EBN consists of $40-60 \%$ of protein, 20 - $30 \%$ carbohydrate, $10-15 \%$ water and trace amount and minerals. Sialic acid, with its major form as $\mathrm{N}$-acetylneuraminic acid (NANA), comprises $9-12 \%$ of the dried wright in the nest [6]. There are two forms of NANA present in EBN: they are either loosely attached on the surface of EBN, namely free form of NANA, or covalently bound to glycan molecules and linked to protein mass, namely conjugated form of NANA. Due to the abundance of N-linked glycans present on EBN [7], the major form of NANA belonged to conjugated form, and thus in general only a trace amount of free NANA was detected on EBN. The amount of free form of NANA has been proposed to be a quality control marker for authentication and categorization of EBN in different grading [8]. At that period of time, microscopic [9] and genetic [10] methods were two commonly used strategies for EBN authentication. However, none of those methods were able to differentiate different grading of EBN.

NANA was proposed to be a major component for antiinfluenza function of EBN [11]. Moreover, NANA could induce the proliferation of cultured Caco-2 cells [12]. From our previous study, both mushroom and human tyrosinase inhibition assay were applied to determine the skin whitening function of different EBN. White and Red EBN showed obvious inhibition effect on tyrosinase activity, while the inhibition effect of Grass EBN is not significant. No inhibition effects on tyrosinase activity for all adulterants of EBN. Moreover, NANA was able to inhibit both mushroom and human tyrosinase activities in dosedependent manner, and which showed a mixed type of inhibition on the enzyme. This activity could explain the skin whitening effect of EBN [13].

\section{Glycoprotein - A Longmystery on EBN}

Protein comprised the largest part of EBN, over half of the nest made of protein. However, the proteomics study was hindered by several limitations. The heavily glycosylated chains of peptide polymer in EBN were very difficult to be hydrolyzed, and thus the rooms for enzymatic reactions were always limited. The first report of protein on EBN, published in 1975 by a French group, indicated that the protein of EBN was actually glycoprotein [14]. Another report in 1977 illustrated the isolation of an enzyme 
- neuraminidase from EBN, However, the origin of this enzyme came from a microbe but not from swiftlet [15]. The next report came up after 10 years, a mitogenic factor was reported in EBN, which expressed epithelial growth factor (EGF)-like activity via functional study approach [16]. Apart from a source of allergic protein reported in 2000 [17,18], no significant progress had been achieved for the following 25 years. Since 2012, an increasing number of reports about the proteomic study of EBN have been published $[19,20]$. Possibly, thanks to the invention and

Table 1:

\begin{tabular}{|c|c|c|c|}
\hline No. & Identified Protein & Year of Published & Library origin \\
\hline 1 & Acidic mammalian chitinase-like [23] & 2017 & Chaetura pelagic \\
\hline 2 & Mucin-5AC-like [23] & 2017 & Chaetura pelagic \\
\hline 3 & Ovoinhibitor-like [23] & 2017 & Chaetura pelagic \\
\hline 4 & Nucleobindin-2 [23] & 2017 & Chaetura pelagic \\
\hline 5 & L5 ka calcium-binding protein [23] & 2017 & Chaetura pelagic \\
\hline 6 & Lysyl oxidase homolog 3 [23] & 2017 & Gallus gallus \\
\hline 7 & Aldoses [25] & 2015 & Gallus gallus \\
\hline 8 & Lactoferrin [26] & 2015 & Gallus gallus \\
\hline 9 & Ovotransferrin [1] & 2015 & Swiss-Prot \\
\hline 10 & Microbial nitrate reductase [1] & 2013 & Swiss-Prot \\
\hline 11 & Emithelial growth factor-like [27] & 2001 & Unknown \\
\hline 12 & Microbial neuraminidase [15] & 1987 & Unknown \\
\hline 13 & Shotease inhibitor homologue [18] & 1977 & \\
\hline
\end{tabular}

In 2013, we had also examined the total anti-oxidation capacity of the EBN by $\mathrm{Cu} 2+$ reduction method, quantified by Trolox standards. The protein of EBN was found to be responsible for the anti-oxidation function, which eventually led to antiageing function. Recently, a Malaysian group reported the finding of two novel peptide from EBN with anti-oxidation function [25]. Nevertheless, the mechanism for such peptide to execute its function on anti-ageing was still a mystery.

\section{Nitrite - A Hidden Threat in EBN}

The discovery of nitrite contamination in 2011, reported by Chinese authority in Zhejiang province, aroused public concern on the safety of EBN consumption. The highest amount of nitrite on EBN (Red blood EBN) could reached 11,000ppm and resulted in a ban on importing EBN immediately. Nitrite is widely used as a preservative, anti-microbial agent, color fixative and flavoring in cured meats and other food products. Nearly all processed meats contain nitrite; however, the usage is under a strict regulation. Nitrite is toxic because of the risk of methemoglobinemia [26]. Patients suffered from methemoglobinemial find difficulty in breathing. Syndromes of nitrite poisoning could be chronic obstructive pulmonary disease [27] and brain tumors in new widely application of mass spectrometry (e.g. Maldi-TOF,ESI LC/ MS/MS Q-TOF, Ion-trap, CHIPS etc.), which makes detail analysis of protein characterization became possible. Followed by the extension in knowledge of protein in EBN, new authentication methods targeting protein identities of EBN were developed as well $[21,22]$. The EBN authentication based on the characterized peptides via the application of peptide HPLC finger printing [23] and monoclonal antibodies [24] have been reported. The identified proteins so fat in EBN are summarized in Table 1. born from the contaminated pregnant woman [28].

A market survey of nitrite content in EBN, supported by Hong Kong Merchant Association of Chinese Medicine, was held immediately after the incident. The median nitrite content of different types of EBN was measured, which ranged from 100$600 \mathrm{ppm}$. Furthermore, under standard processing method, up to $98 \%$ of nitrite could be removed from EBN, and subsequently nitrite was not detected in stewed EBN. On the other hand, the origin of nitrite contamination was still a mystery. To search the source of nitrite, droppings from swiftlets and water samples were collected from the production sites of EBN in Malaysia and Indonesia, and which contained a high amount of nitrate, instead of nitrite. In parallel, the protein extract of EBN was subjected to proteomics analysis. A microbial nitrate reductase was identified by mass spectroscopy, which converted nitrate to nitrite in EBN. A specific inhibitor of nitrate reductase, when added in the developing EBN, successfully abolished the nitrate reduction activity found in EBN, which subsequently reduced the final content of nitrite in EBN. This phenomenon was successfully proven by the field study [29]. Thus, the nitrite on EBN could be a result of the contaminating and nitrate and the microbial nitrate reductase from the environment (Figure 1) [29]. 
1
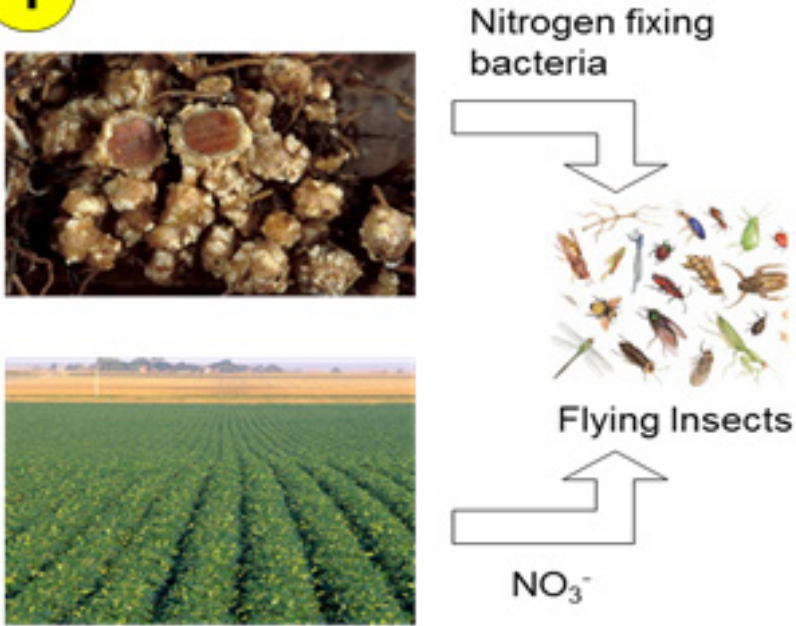

Flying Insects

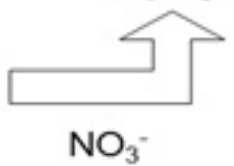

\section{6}

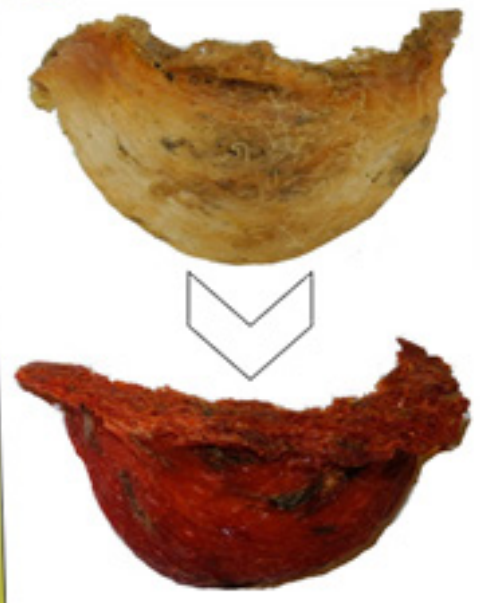

5

$>31^{\circ} \mathrm{C} ; \mathrm{pH}$;

Relative humidity $\sim 64-69 \%$

Nitrate reductase

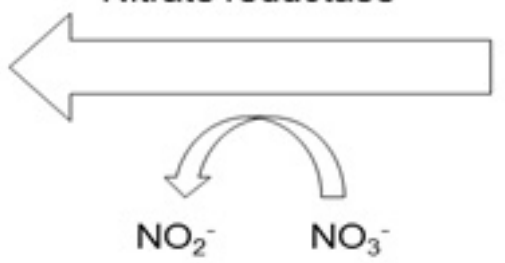

2

Swiftlet intakes

flying insects

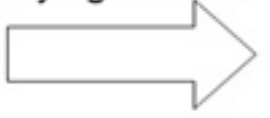

Aerodramus fuciphugas
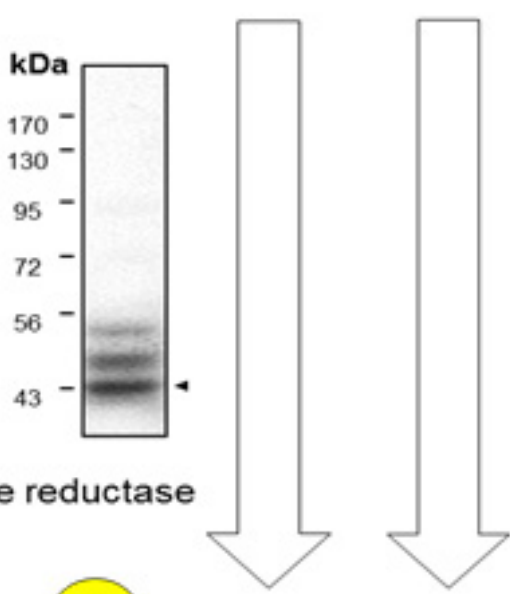

3

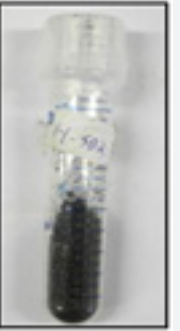

$\mathrm{NO}_{3}{ }^{*}$

\section{4}

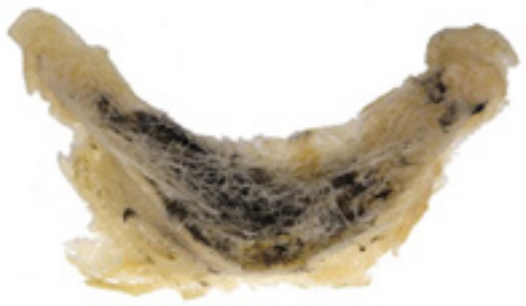

$\left[\mathrm{NO}_{2}^{-}\right]$

Figure 1: Proposed origin and pathway for nitrite contamination onEBN.

(1): The root nodules of plant on island type habitat contain abundant nitrogen fixing bacteria. Also, fertilizers applied on the crops land contain high amount of nitrate.

(2): Nitrate and nitrogen fixing bacteria accumulate in swiftlet through the intakes of contaminated flying insects.

(3): High content of nitrate has been found in swiftlet's droppings, and nitrate reductase deriving nitrogen fixing bacteria has been identified in EBN.

(4): The nest is made of the salivary secretion of the swiftlet and embedded with droppings at the centre of the nest.

(5): Under favourable environment, nitrate reductase convert nitrate to nitrite efficiently.

(6): EBN is changed from white to yellow and then red due to the accumulation of nitrite.

Although the illustration of safe consumption method for EBN, the industry still suffers from dramatic economic loss until 2014. The global market value of EBN was evaporated by thirty percent after the nitrite incident in 2011, but which was recovered to its original value after 2016 [30]. We are quite certain that what we achieved and described above was just a beginning. More innovative applications of using EBN materials will become notable in the near future. 


\section{Acknowledgement}

This study was supported by Hong Kong RGC Themebased Research Scheme (T13-607/12R), Innovation Technology Fund (UIM/288, UIM/302, UIM/340, UIT/137, ITS/022/16FP), TUYF15SC01, Shenzhen Science and Technology Committee Research Grant (JCYJ 20160229205726699, JCYJ 20160229205812004, JCYJ 20160229210027564, CKFW 2016082916015476, JCYJ 20170413173747440, ZDSYS 201 707281432317 and 20170326). Z.W. received a scholarship from HKJEBN Limited.

\section{References}

1. Yida Z, Imam MU, Ismail M, Hou Z, Abdullah MA, et al. (2015) Edible Bird's Nest attenuates high fat diet-induced oxidative stress and inflammation via regulation of hepatic antioxidant and inflammatory genes. BMC Complement Altern Med 15: 310.

2. Guo CT, Takahashi T, Bukawa W, Takahashi N, Yagi H, et al. (2006) Edible bird's nest extract inhibits influenza virus infection. Antivira Res 70(3): 140-146.

3. Haghani A, Mehrbod P, Safi N, Kadir FA, Omar AR, et al. (2017) Edible bird's nest modulate intracellular molecular pathways of influenza A virus infected cells. BMC Complement Altern Med 17(1): 22.

4. Matsukawa N, Matsumoto M, Bukawa W, Chiji H, Nakayama K, et al. (2011) Improvement of bone strength and dermal thickness due to dietary edible bird's nest extract inovariectomized rats. Biosci Biotechnol Biochem 75(3): 590-592.

5. Kang N, Hails CJ, Sigurdsson JB (1991) Nest construction and egglaying in edible-nest swiftlets Aerodramus spp. and the implications for harvesting. IBIS 133: 170-177.

6. Marcone MF (2005) Characterization of the Edible Bird's Nest the "Caviar of the East". Food Research International 38(100: 1125-1134.

7. Yagi H, Yasukawa N, Yu SY, Guo CT, Takahashi N, et al. (2008) The Expression of sialylated high-Antennary N-glycans in edible bird's nest. Carbohydrate Research 343(8): 1373-1377.

8. Chan GK, Zheng KY, Zhu KY, Dong TT, Tsim KW et al. (2013a) Determination of free $\mathrm{N}$-acetylneuraminic acid in edible bird nest: A development of chemical marker for quality control. Journal of Ethnobiology and Traditional Medicine 120: 620-628.

9. Lin JR, Zhou H, Lai X (2006) Application of Stereoscopy on Edible Bird's Nest Identification. Journal of Chinese Medicinal Materials 29(3): 219221.

10. Lin JR, Zhou H, Lai XP, Hou Y, Xian XM, et al. (2009) Genetic Identification of edible birds' nest based on mitochondrial DNA sequences. Food Research International 42(8): 1053- 1061.

11. Guo CT, Takahashi T, Bukawa W, Takahashi N, Yagi H, et al. (2006) Edible Bird's Nest Extract Inhibits Influenza Virus Infection. Antiviral Res 70(3): 140-146.

12. Rashed AA, Nazaimoon WM (2010) Effect of Edible Bird's Nest on Caco-2 Cell Proliferation. Journal of Food Technology 8: 126-130.

13. Chan GK, Wong ZC, Lam KY, Cheng LK, Zhang LM, et al. (2015) Edible bird's nest, an Asian health food supplement, possesses skin lightening activities: identification of $\mathrm{N}$-acetylneuraminic acid as active ingredient. Journal of Cosmetics, Dermatological Sciences and Applications 5(4): 262-274.
14. Houdret N, Lhermitte M, Degand P, Roussel P (1975) Purification and chemical study of a Collocalia glycoprotein. Biochimie 57(5): 603-608.

15. Flashner M, Wang P, Hurley JB, Tanenbaum SW (1977) Properties of an inducible extracellular neuraminidase from an Arthrobacter isolate. ] Bacteriol 129(3): 1457-1465.

16. Ng MH, Chan KH, Kong YC (1986) Potentiation of mitogenic response by extracts of the swiftlet's (Collocalia) nest. Biochem Int 13(3): 521531.

17. Goh DL, Chew FT, Chua KY, Chay OM, Lee BW (2000) Edible "bird's nest"-induced anaphylaxis: An under-recognized entity? J Pediatr 137(2): 277-279.

18. Ou K, Seow TK, Liang RC, Lee BW, Goh DL, et al. (2001) Identification of a serine protease inhibitor homologue in Bird's Nest by an integrated proteomics approach. Electrophoresis 22(16): 3589 - 3595.

19. Liu X, Lai X, Zhang S, Huang X, Lan Q, et al. (2012) Proteomic profile of edible bird's nest proteins. J Agric Food Chem 60(51): 12477-12481.

20. Liu L, Li XL, Gao JP, Kong YJ, Wang ML, et al. (2013) Peptides analysis in digested edible bird's nest by HPLC-MS. Zhongguo Zhong Yao Za Zhi 38(5): 714-719.

21. Zhang S, Lai X, Liu X, Li Y, Li B, et al. (2013) Development of monoclonal antibodies and quantitative sandwich enzyme linked immunosorbent assay for the characteristic sialoglycoprotein of edible bird's nest. J Immunoassay Immunochem 34(1): 49-60.

22. Tukiran NA, Ismail A, Mustafa S, Hamid M (2015) Enzyme immunoassay for the detection of porcine gelatine in edible bird's nests. Food AdditContam Part A Chem Anal Control Expo Risk Assess 32 (7): 10231028.

23. Wong CF, Chan KL, Zhang ML, Yao P, Lin HQ et al. (2017) Characterization of edible bird's nest by peptide fingerprinting with principal component analysis. Food Quality and Safety 1(1): 83-92.

24. Wong CF, Chan KL, Wu L, Lam HN, Yao P, et al. (2018) A comprehensive proteomics study on edible bird's nest using new monoclonal antibody and application in quality control. Journal of Food Composition and Analysis 66(2018): 145-151.

25. Ghassem M, Arihara K, Mohammadi S, Sani NA, Babji AS (2017) Identification of two novel antioxidant peptides from edible bird's nest (Aerodramusfuciphagus) protein hydrolysates. Food Funct 8(5): 20462052.

26. Orgeron JD, Martin JD, Caraway CT, Martine RM, Hauser GH (1957) Methemoglobinemia from eating meat with high nitrite content. Public Health Rep 72: 189-193.

27. Jiang R, Paik DC, Hankinson JL, Barr RG (2007) Cured meat consumption, lung function, and chronic obstructive pulmonary disease among United States adults. Am J Respir Crit Care Med 175(8): 798-804.

28. Pogoda JM, Preston-Martin S (2001) Maternal cured meat consumption during pregnancy and risk of pediatric brain tumour in offspring: potentially harmful levels of intake. Public Health Nutrition 4(2): 183189.

29. Chan GK, Zhu KY, Chou DJ, Guo AJ, Lau DT, et al. (2013b) Surveillance of nitrite level on edible bird's nest in Hong Kong: evaluation of removal method and proposed origin of contamination. Food Control 34: 637644.

30. Leung CY (2004) Three billions market competition for edible bird's nest shops. Economic Digest 1197: 68-69. 
This work is licensed under Creative Commons Attribution 4.0 License

DOI: 10.19080/JCMAH.2018.06.555683

\section{Your next submission with Juniper Publishers} will reach you the below assets

- Quality Editorial service

- Swift Peer Review

- Reprints availability

- E-prints Service

- Manuscript Podcast for convenient understanding

- Global attainment for your research

- Manuscript accessibility in different formats

( Pdf, E-pub, Full Text, Audio)

- Unceasing customer service

Track the below URL for one-step submission https://juniperpublishers.com/online-submission.php 